\title{
10 \\ Is Criminal Law Reform a Lost Cause?
}

\author{
Simon Bronitt ${ }^{1}$
}

\section{Introduction: The Agendas of Criminal Law Reform in the 1990s}

In the 1990s, criminal law reform in Australia, as in the United Kingdom, was foremost a technical exercise in rationalising legal doctrine (found in common law and statutes) in order to resolve ambiguity and modernise the law. ${ }^{2}$ More progressively, law reform commissions, in ongoing partnership with the legal academy, set about devising new templates for the criminal law founded on codification. In the United Kingdom, this work by The Law Commission resulted in the Draft Criminal Code for England and Wales in 1989. ${ }^{3}$ In Australia, criminal law reform followed a similar path, beginning with a review of federal criminal law in 1989, subsequently spawning a program of national harmonisation in the Model Criminal Code (MCC) project, and the enactment of Criminal Code Act 1995 (Cth).

\footnotetext{
1 TC Beirne School of Law, University of Queensland. I would like to thank Michael Potts and Zoe Brereton for research assistance.

2 Under its parent Act, The Law Commission (England and Wales) was tasked with keeping the law under review 'with a view to its systematic development and reform, including in particular the codification of law': Law Commissions Act 1965 (UK) c 22, s 3.

3 The Law Commission, A Criminal Code for England and Wales, Consultation Paper No 177 (1989) Vols 1 and 2.
} 
The reform programs in the United Kingdom and Australia adhered to similar formats. The normative resources for criminal law reform were limited to a narrow set of guiding principles promoting the liberal values of certainty, coherence, and fairness. Little, if any, thought was given to the criminal law as a tool of public policy or regulation, or even how criminal laws operated in practice; namely, how legal definitions, defences or rules of evidence and procedure were mediated, and sometimes even subverted, by police culture, prosecutorial and trial practice, or jury directions. Empirical perspectives on the operation of the law were gleaned only incidentally through the public submission processes, which solicited 'real world' experiences from professional experts and interest groups.

Institutional law reform in the 1990s, reflecting the professional backgrounds and skills of the judges and legal academics involved, tended to focus narrowly on 'lawyers' law', disregarding broader issues of empiricism which had animated the legal realism and sociolegal studies movement a century earlier: the questions of why, when and how the 'law in books' diverged from the 'law in action'. 'Without addressing such critical contextual questions, insights from social science, psychology or criminology rarely informed recommendations about the proper direction of reform. As a result, key questions related to regulatory effectiveness were rarely addressed, namely whether criminalisation would produce the aims of policymakers, or conversely result in unintended (even counterproductive) consequences.

For the purposes of institutional law reform, the guiding normative resources were based on three perspectives or sub-disciplines:

- Comparative law, for reflecting on progress made in similar 'advanced' common law jurisdictions; 5

- Legal history, for tracing the genealogy of common law doctrine, legislative reform and learned academic writings in a particular field; ${ }^{6}$

4 A gap first identified by Roscoe Pound in his influential article, 'Law in Books and Law in Action' (1910) 44 American Law Reports 12.

5 In the UK, comparative research rarely ventured beyond surveys of other comparable 'developed' common law systems of Australia, Canada and New Zealand.

6 Legal history rarely ventured beyond examining formal sources of law, ignoring the wider sociocultural, political and economic influences shaping legal development. Cf A Norrie, Crime, Reason and History: A Critical Introduction to Criminal Law (Cambridge University Press, $2^{\text {nd }}$ edn, 2001); L Farmer, Criminal Law, Tradition and Legal Order (Cambridge University Press, 1997). 
- Legal theory, for invoking philosophical ideas, values and principles (with primacy accorded to liberal values) to underpin or undermine specific reform proposals. ${ }^{7}$

This failure to engage with external, contextual perspectives on the criminal law - to move beyond what Nicola Lacey has termed the 'immanent' or internal critiques of legal doctrine ${ }^{8}-$ severely limited the capacity of law reform commissions to drive significant legal change. ${ }^{9}$

There are some notable exceptions where law reform inquiries did venture beyond its disciplinary boundaries. For example, in its review of homicide law, The Law Commission of England and Wales funded an empirical study investigating public opinion relating to homicide severity. This groundbreaking research revealed the extent to which moral intuitions about offence seriousness in the general public did not always match the view of criminal law theorists, or indeed law reformers, especially in relation to felony murder. ${ }^{10}$ But fundamentally, criminal law reform remained a liberal enterprise, a technical job for legal scholars and academically-minded judges committed to rationalising, simplifying and modernising the tangled mess of common law and ad hoc statutes.

In his millennial essay, the distinguished legal scholar Professor Andrew Ashworth posed the question whether 'criminal law is a lost cause'. ${ }^{11}$ His conclusion then, as now, is that the quest for a more principled criminal law, one achieving better conformity between principles and legal doctrine, has proven highly elusive. Ashworth's assessment would equally apply to Australia, and to the impact of law reform. But this essay poses the question in a different form - whether criminal law reform is a lost cause - and, more significantly, draws different conclusions. The essay asks whether the 'liberal promise' of a more principled and codified criminal law should be exhaustive of our aspirations for criminal law reform.

7 See, for example, The Law Commission, Consent in the Criminal Law: A Consultation Paper, Consultation Paper No 139 (1995), app C.

8 N Lacey, 'Legal Constructions of Crime', in M Maguire, R Morgan and R Reiner (eds), The Oxford Handbook of Criminology (Oxford University Press, $4^{\text {th }}$ edn, 2007) 192.

9 See discussion in S Bronitt and McSherry, Principles of Criminal Law (Lawbook Co, $4^{\text {th }}$ edn, 2017), [1.185]ff.

10 B Mitchell, 'Public Perceptions of Homicide and Criminal Justice' (1998) 38(3) British Journal of Criminology 453, 459; see also B Mitchell, 'Further Evidence of the Relationship between Legal and Public Opinion on the Law of Homicide' [2000] Criminal Law Review 814.

11 A Ashworth, 'Is the Criminal Law a Lost Cause?' (2000) 116 Law Quarterly Review 225, 232. 
Part II provides a reflection on the impact of institutional law reform over the past quarter-century upon the criminal law in Australia, assessing the reasons for the prevailing 'parochial codiphobia' which resists codification, uniformity or even harmonisation at the national level. ${ }^{12}$ Freed from the present obsession with general principles and codification, ${ }^{13}$ criminal law reform needs to be $r$-formed, drawing upon a broader array of resources - disciplinary and methodological as well as financial - than are typically available to existing institutional law reform bodies. Part III provides an overview of the ad hoc bodies also engaged in law reform, examining the reform agenda of the current Royal Commission into Institutional Child Sexual Abuse. The essay assesses whether these new agents of law reform, although not without limitations, are better positioned to tackle reform in a more systemic, holistic and contextual manner, harnessing relevant disciplinary and empirical knowledge to produce better policy outcomes.

\section{Model Criminal Laws and the False Promise of Codification?}

As noted above, the approach to criminal law reform in Australia in the 1980s and 1990s was not dissimilar to that in the United Kingdom, codification being the main priority in both jurisdictions. In the United Kingdom, The Law Commission, assisted by a 'Dream Team' of leading criminal law scholars, ${ }^{14}$ was tasked to prepare a draft Criminal Code for England and Wales. Contemporaneously in Australia, the federal AttorneyGeneral commissioned former High Court Justice Sir Harry Gibbs to lead the Review of Commonwealth Criminal Law, with a view to codifying its general principles. ${ }^{15}$ While the Gibbs Review laid the foundations for the Criminal Code Act 1995 (Cth), the proposal for codification in the United Kingdom encountered stronger opposition when published

12 The term 'codiphobia' was first coined in the 1850s by Professor Amos to describe the legislative hostility to codification: discussed in A Hemming, 'When Is a Code a Code?' (2010) 15(1) Deakin Law Review 65, fn 9. My adaptation of this neologism is offered in the spirit of Jeremy Bentham, who first coined the term 'codification'. See discussion in S Bronitt, 'Towards a Universal Theory of Criminal Law: Rethinking the Comparative and International Project' (2008) 27 Criminal Justice Ethics 53.

13 See L Farmer, 'The Obsession with Definition: The Nature of Crime and Critical Legal Theory' (1996) 5 Social and Legal Studies 57.

14 The team comprised Sir John Smith, Edward Griew and Ian Dennis: P Roberts, 'Philosophy, Feinberg, Codification, and Consent: A Progress Report on English Experiences of Criminal Law Reform' (2001) 5 Buffalo Criminal Law Review 173, 194.

15 H Gibbs, R Watson and A Menzies, Review of Commonwealth Criminal Law: Final Report (1991). 
in 1989. Ultimately the draft was shelved as a legislative project, doomed to gather dust and haunt the footnotes of academic textbooks. Australia, by contrast, was more receptive to codification. This was unsurprising in light of the success of codification a century earlier, when Sir Samuel Griffith embarked on the modernisation of Queensland's criminal law that led to the passage of the highly influential Criminal Code 1899 (Qld). ${ }^{16}$

Building on the momentum following the completion of the Gibbs Review in 1988, the Standing Committee of Attorneys-General (SCAG) established an intergovernmental Model Criminal Code Officers Committee (MCCOC) to draft a Model Criminal Code (MCC) for Australia. The lack of uniformity in Australia's criminal law in the late 1980s became a focus of concern of these senior officials working in the Attorneys-Generals' Departments of the Commonwealth, states and territories. Extending the federal ambition for codification of general principles to a national level was never going to be easy. The selling point for the MCC was framed in terms of traditional liberal rationale for codification: as one member of the MCCOC noted, codification would make the criminal law 'easy to discover, easy to understand, cheap to buy, and democratically made and amended'. ${ }^{17}$

Implementation, however, has proved to be a stumbling block, with selective and piecemeal uptake of the MCC. ${ }^{18}$ Even regarding the Commonwealth, Australian Capital Territory and Northern Territory, the degree of uniformity achieved has been partial and approximate, focused primarily on implementation of the 'general part' of the MCC dealing with principles of responsibility. Notwithstanding the significant time, effort and costs devoted to the MCC project, ${ }^{19}$ as one commentator noted, 'the political impetus to advance the unification of criminal law through a common code appears to have waned for the time being, and a profound divide between the two major worlds - the Griffith-based codes and the "common law states" - remains'. ${ }^{20}$

16 See R S O’Regan, 'Sir Samuel Griffith's Criminal Code' (1991) 7(2) Australian Bar Review 141 and D Wells, “"The Griffith Code" - Then and Now' (1994) 3(2) Griffith Law Review 205.

17 M Goode, 'Codification of the Australian Criminal Law' (1992) 16 Criminal Law Journal 5, 8.

18 Ibid. 226, 234.

19 M Goode, 'Constructing Criminal Law Reform and the Model Criminal Code' (2002) 26 Criminal Law Journal 152.

20 S Tarrant, 'Building Bridges in Australian Criminal Law: Codification and the Common Law' (2013) 39(3) Monash University Law Review 838, 840 (footnote omitted); see also S Bronitt and M Gani, 'Criminal Codes in the $21^{\text {st }}$ Century: The Paradox of the Liberal Promise', in B McSherry, A Norrie and S Bronitt (eds), Regulating Deviance: The Redirection of Criminalisation and the Futures of Criminal Law (Hart Publishing, 2009) 235-60. 
Reform of Australia's criminal law should neither be defined nor limited by the dual aims of codification and uniformity, which have proved elusive not only because of the 'code' and 'non-code' divide, but also because of the prevailing political discourse of sovereign states' rights in the field of 'law and order'. This has meant that, across many significant fields of the criminal law, law reform has occurred at variable speeds, sometimes separated by decades. For example, the 'marital rape immunity' was repealed by the New South Wales Parliament on 15 May 1981 through the enactment of the Crimes (Sexual Assault) Amendment Act 1981 (NSW), 11 years before its repeal in South Australia by way of the Criminal Law Consolidation (Rape) Amendment Act 1992 (SA). Similarly, the decriminalisation of same sex intercourse was first addressed by South Australia through The Criminal Law (Sexual Offences) Amendment Act 1975 (SA), while Tasmania was the last jurisdiction to enact amending legislation in $1997 .{ }^{21}$

What causes 'variable speed' law reform? One cause undoubtedly relates to the fact that federal parliament does not possess plenary power vis-avis criminal law, only having the power to enact offences 'incidental' to other heads of power under the Constitution. Consequently, criminal law remains the primary responsibility of each state and territory, rendering it especially vulnerable to local 'law and order' politics. ${ }^{22}$ Commonly heard claims of jurisdictional uniqueness, especially at election time, undoubtedly impede national consensus about the necessity, direction and pace of law reform. While in other fields 'cooperative federalism' has operated to forge national consensus and policy convergence between jurisdictions, a condition of 'uncooperative federalism' has prevailed.

Having identified the structural limitations facing institutional criminal law reform at national and local levels, I turn in Part III to whether ad hoc public inquiries - such as Royal Commissions - would be better equipped for this purpose.

21 Criminal Code Amendment Act 1997 (Tas).

22 R Hogg and D Brown, Rethinking Law and Order (Pluto Press, 1998), Ch 1; see also D Weatherburn, Law and Order in Australia: Rhetoric and Reality (Federation Press, 2004). 


\section{Ad Hoc Law Reform: Royal Commissions and Other Public Inquiries}

The Australian Law Reform Commission undertook an inquiry into the roles and functions of Royal Commissions and other public inquiries in $2009 .^{23}$ While the use of ad hoc public inquiries is longstanding, their purposes have changed over time. In the $19^{\text {th }}$ century, for example, various criminal law commissions were established in the United Kingdom and its colonies to consider reform. Heavily influenced by Benthamite ideals, ${ }^{24}$ ad hoc commissions can be viewed as the embodiment of liberal modernity, aspiring to rationalise, consolidate, and, where possible, codify the tangled mess of common law and statutory modifications.

The advent of more investigative Royal Commissions in the $20^{\text {th }}$ century had little in common with these earlier commissions. Beyond exercising wide inquisitorial fact-finding powers, these bodies were empowered to make recommendations for reform. Royal Commissions, however, have a somewhat mixed track-record in term of law reform. For example, the Royal Commission into Aboriginal Deaths in Custody (1987-1991) placed a spotlight on the issue, and developed an ambitious program of national reform, though implementation over the subsequent decades has been painfully slow. ${ }^{25}$ More recently, the Royal Commission into Institutional Child Sexual Abuse (2013-present) has been highly successful in drawing attention to historic and ongoing abuse within institutional settings, with an investigative function matched by a significant agenda of national policy development and law reform. ${ }^{26}$ The merits of ad hoc commissions are that they are constituted for a specific purpose, undertake extensive fact-finding, garner expertise from wherever it exists, and demand more public and political attention than standing law reform bodies, which in the field of criminal law tend to generate reports that sit on shelves gathering dust.

23 Australian Law Reform Commission, Making Inquiries - A New Statutory Framework, Report No 111 (2009).

24 See W Holdsworth, A History of English Law (Sweet \& Maxwell, $7^{\text {th }}$ edn, 1971) Vol 13, 272.

25 See T Sansbury, 'State and Territory Implementation of the Recommendations of the Royal Commission' (2001) 5(8) Indigenous Law Bulletin 6.

26 See Royal Commission into Institutional Responses to Child Sexual Abuse, Terms of Reference (13 November 2014), www.childabuseroyalcommission.gov.au/about-us/terms-of-reference. 
A strong contrary view has been put forward by the distinguished judge and jurist, Ron Sackville. Reviewing the relative merits of standing law reform bodies over ad hoc commissions or inquiries, Sackville pointed to the high degree of functional overlap, since both bodies: invite or seek input on policy through public consultation; maintain a degree of independence from the executive; confer democratic legitimacy since both are constituted by statute, and recommendations, if implemented, are done so by an elected parliament; ${ }^{27}$ and receive terms of reference from the executive, ensuring accountability to government. ${ }^{28}$ According to Sackville, the key difference between these two bodies relates to longevity: Royal Commissions are ad hoc and time-limited processes, while law reform bodies are permanent. ${ }^{29}$ The former are not dominated by lawyers, and often frequently inquire into areas that would not be viewed as within the remit of law reform, even in its broadest sense. Citing the Fitzgerald Inquiry (1987-1989) as an example, Sackville concluded that far-reaching reform in electoral matters and governmental transparency in Queensland would probably never have been addressed by a law reform agency. That said, he concluded the differences may not be as great as they first appear, with significant overlap in terms of the range of matters reviewed and recommendations made. ${ }^{30}$

From a systemic perspective, Sackville concluded this functional overlap was duplicative and wasteful. Also, many of the issues tackled were ongoing, leading some ad hoc commissions to call for the establishment of standing bodies to govern the subject matter into which they are inquiring. Sackville concluded that standing law reform agencies, given their relative low cost and specialisation in undertaking inquiries, should assume (at least in part) the law reform functions of Royal Commissions. ${ }^{31}$

I do not share Sackville's assessment of comparative advantage for the following reasons. First, in terms of 'value for money', law reform agencies look much less impressive when implementation records are compared. Secondly, Sackville's view of enhanced 'specialisation' within

27 R Sackville, 'Law Reform Agencies and Royal Commissions: Toiling in the Same Field?' in B Opeskin and D Weisbrot (eds), The Promise of Law Reform (Federation Press, 2005) 274, 281.

28 This makes the timing and tailoring of such inquiries inherently political and vulnerable to misuse: ibid. 284 .

29 That said, Royal Commissions often examine matters not initially contemplated by the governments that established them: ibid. 281.

30 Ibid. 283.

31 For a similar viewpoint, see D Weisbrot, 'The Future for Institutional Law Reform', in B Opeskin and D Weisbrot (eds), The Promise of Law Reform (Federation Press, 2005) 18, 22. 
standing law reform agencies is restricted to legal knowledge and research methods, overlooking broader interdisciplinary capabilities and resources potentially available to ad hoc bodies. Regarding the latter, ad hoc commissions are better placed to harness and coordinate a wider diversity of expertise and inputs into the policy change and law reform processes, and to approach the 'problem' in a more systemic, holistic and contextual manner. Importantly, ad hoc bodies are not limited to recommending legal solutions, but can examine a much wider range of policy options including, but not limited to, law reform. Another advantage is that the ad hoc model tends to attract more public and political attention than the work of standing agencies, which, though independent from government, receive less attention when their reports are released. Even with the advent of executive summaries and media releases, a technical law reform commission final report on the law of complicity, for example, is unlikely to attract much interest beyond a small group of practitioners, judges and academics. Finally, like a jury, which commands great power for only a brief moment in time, the ad hoc body may achieve a higher degree of practical independence than a standing body, whose organisational culture and independence may ultimately be negatively affected by governmental clientelism and budgetary insecurity. ${ }^{32}$

\section{Conclusion}

For much of the past two decades, criminal law reform has focused on the dual related agendas of codification and harmonisation, though the realisation of the liberal promise for the criminal law has been hampered by 'parochial codiphobia' and an 'uncivil' politics of law and order. As a consequence, many carefully researched and considered recommendations of standing law reform bodies remain unimplemented. The precise extent of this 'implementation deficit' is unknown, which is surprising in the modern era of new public management with its emphasis on impact and performance measurement in the public sector.

32 The erosion of funding and government support for institutional law reform is outlined in a Submission by former ALRC President, David Weisbrot, to the Senate Legal and Constitutional Committee, 28 January 2011: www.aph.gov.au/Parliamentary_Business/Committees/Senate/Legal_ and_Constitutional_Affairs/Completed_inquiries/2010-13/lawreformcommission/submissions. 
Perhaps it is time to return to investigate more fully the relationship between ad hoc and standing law reform bodies, and how the beneficial aspects these various bodies and processes can be harnessed and better coordinated. In my view, the benchmark for 'good' or 'better' criminal law reform should be the same that applies to public policy generally: is reform based on the best available evidence, and informed by expert opinion? Expertise in this context should not be limited to the judiciary, profession and legal academy. My contextual approach to reform requires a stronger commitment to empiricism, but also proactive engagement with the wider community. This will provide a better understanding of the complexity of the problem, as well as enhance the legitimacy of the reform process. The ad hoc model ultimately favoured in this essay does carry some risk of increased cost, delay and political misuse - though in this respect, the model is no different from those risks associated with the current 'mixed' system. 
This text is taken from New Directions for Law in Australia: Essays in Contemporary Law Reform, edited by Ron Levy, Molly O’Brien, Simon Rice, Pauline Ridge and Margaret Thornton, published 2017 by ANU Press, The Australian National University, Canberra, Australia. 